\title{
Species aspects of breeding herbage varieties for northern marginal regions
}

\author{
ODD ARNE ROGNLI
}

Department of Genetics and Plant Breeding, Agricultural University of Norway, $\mathrm{N}-1432$ Ass-NLH, Norway

\begin{abstract}
Northern marginal regions are very heterogeneous as regards environmental conditions for plant growth. Low temperature is the overriding feature of the environment in these regions. This paper discusses species aspects in relation to breeding for adaptation to northern marginal regions for the most important herbage species. The impact of natural selection and climatic adaptation on the herbage plant populations at the margin forms the basis for discussing breeding objectives for the various species in these regions. The differences between species native to these regions, e.g. Poa pratensis, Festuca rubra, Deschampsia spp., and introduced species like Phleum pratense and Festuca pratensis, are emphasized. These differences include important characteristics like yield potential, seasonal distribution, quality and winterhardiness, the most important characteristic of adaptation to northern marginal regions. The influence of the course of the reproductive development on both total yield, harvest index and seasonal distribution is stressed, and particularly discussed for Phleum.
\end{abstract}

Index words: herbage grass breeding, native species, introduced species, ecotypes, low-input agriculture

\section{Introduction}

Geographically, »northern marginal regions" should be understood as areas close to and north of the Arctic Circle, and these include the northernmost parts of Norway, Sweden and Finland, Iceland, the Faroe Islands, Greenland, Alaska and the northern parts of the USSR (LOMAKKA 1958). There is a tremendous variation in climatic conditions within these regions. In ecological terms, a marginal or extreme environment often has one single environmental factor that limits plant growth (BRADSHAw 1971). Low temperature is the single most important feature of the environment at higher latitudes. Most of the valuable herbage species are at the margin of their distribution in these regions.

The importance of herbage production in northern marginal regions is recognized. Roughly speaking, $60-100 \%$ of the agricultural land is made up of leys and permanent pastures. High frequency of peat and bog soils and, generally, low soil $\mathrm{pH}$, in combination with wet and cold climate during short growing seasons, impose very heavy strains on her- 
bage plants at higher latitudes, especially under the modern cultivation techniques (Schjelderup 1983 a). The present topic is very wide and complex. Therefore, this presentation is not an attempt to give a complete coverage of the field.

\section{Plant adaptation and species strategies in northern marginal regions}

\section{Natural selection}

The physical environment generates high and directional selection pressures in marginal regions (BRADSHaw 1971). Adaptation is for survival ability as opposed to competitive ability in more optimal environments. During transplantation of temperate populations of cultivated species to arctic and subarctic regions, the cumulative mortality has often been nearly $100 \%$, and therefore most of the northern populations and cultivars of valuable herbage species have a fairly narrow genetic background. However, studies of plant populations from northern marginal regions have shown that they are very heterogeneous, with much more genetic variability than expected (Tigerstedt 1985). Introduction of southern Medicago spp. and Trifolium spp. populations to Alaska, is a recent example of conscious use of natural selection in the adaptation of new species (KLEBESAdel 1985).

\section{Characteristics of herbage plant life forms at higher latitudes}

The typical plant life form of arctic and alpine environments is an herbaceous perennial with a relatively large root and/or rhizome system (BILlings 1974). The large root system may: 1) increase the efficiency of nutrient uptake from cold soils, 2) serve as storage organs for carbohydrates which secure both development of winterhardiness, survival under a long-lasting snow cover and early leaf development in spring, and 3) increase the competitive ability through vegetative propaga- tion. These characteristics are advantageous in short and cold growing seasons. Polyploidy and vegetative reproduction by vivipary and apomixis, are very common among the arctic grass species (FloviK 1938). Polyploid species are very heterozygous, a feature that probably is responsible for physiological stability on the enzyme level during strong temperature fluctuations (TIGERSTEDT 1985). Initiation and differentiation of flowerbuds in the autumn render the arctic plant species able to set mature seed in the very short summer. In combination with apomixis and rhizomatous roots, it gives optimal Darwinian fitness in high-latitude environments.

\section{Ecotypic differentiation}

Clinal variation (ecotypes) is the most important adaptive strategy in species with a wide geographic distribution. Studies of natural and semi-natural populations of herbage grasses, show strong ecotypic differentiation in response to daylength and temperature for a number of important herbage plant characteristics, e.g. photosynthesis and growth rate (Heide 1985; Solmaug 1985), seasonal growth rhythm and dry matter distribution (Foss 1968; EAgLes and ØSTGẢRD 1971), flowering response (НА̉BJørg 1979 a; HeIDE 1980, 1982) and growth cessation and development of cold hardiness. The critical photoperiods for vegetative growth and flower induction, events that strongly influence the pattern of dry matter distribution, are very long in these ecotypes. When grown at lower latitudes they start growing later in the spring, and growth ceases earlier in the autumn. Ecotype studies have taught us a lot about the mechanisms that contribute to optimal fitness under different environmental conditions. Owing to the unique environmental conditions in northern marginal regions, well-adapted ecotypes or adapted cultivars must be the main genetic resources of herbage breeding programmes for these regions (SIMONSEN 1985). 


\section{Species aspects in relation to breeding objectives}

The main breeding objectives for northern marginal regions have been discussed by SimONSEN (1985). In the following, the herbage species aspects will be discussed in relation to the main breeding objectives.

Lolium spp. dominate herbage production in Europe today. The great variations in climate, soil and management conditions in northern marginal regions make it necessary to use several species (Simonsen 1985). Phleum pratense is the dominating species in younger sown meadows in Scandinavia, while Agrostis tenuis and Poa pratensis dominate in older meadows (NeSHEIM 1986). In pastures and permanent grasslands, Poa pratensis, Agrostis tenuis, Festuca rubra and Deschampsia caespitosa are the most important species. In addition, $D$. caespitosa and $D$. beringensis are interesting species for forage production both in Iceland and in Alaska (THOMAsson 1984). In Northern Sweden and Finland, breeding efforts are concentrated on timothy, meadow fescue and red clover (HAGSAND 1985; Ravantti and Kajaste 1986).

\section{Herbage yield and seasonal distribution}

Northern ecotypes have a specific growth rhythm that is important for high production and survival at higher latitudes. The relative amount of dry matter produced in the first cut increases with increasing latitude of origin (Foss 1968, Klebesadel and Helm 1986). Schuelderup (1983 b) found that Phleum pratense and Poa pratensis had the highest spring growth rate in the north, while Festuca pratensis and Dactylis glomerata exhibited a higher growth rate in the south in this period. In the second cut, the growth rate was highest in the south for all species, except for Poa pratensis. This underlines the highlatitude adaptation of Poa, and the wellknown fall dormancy in the north. Following shorter days in late summer there is a switch from leaf growth to carbohydrate storage in the crowns, with related development of cold hardiness and frost resistance. In this context we may ask: Can the seasonal distribution of dry matter be altered by breeding without any adverse effects on winterhardiness? Based on the experience from numerous studies of winterhardiness in northern marginal regions, I would say no. This is especially so if high persistency is required. In breeding cultivars for short-term leys, it may be possible to stretch the period of growth in the fall, without decreasing winterhardiness too much.

The potential for biomass production is remarkably high in northern regions. SIMONSEN (1985) presented results showing that timothy and meadow fescue, cut twice, yielded nearly the same at northern and southern latitudes in Fennoscandia, while cocksfoot yielded less in the north than in the south. However, because more than two cuttings can be taken, the total annual dry matter yield will be higher in the south. Deinum et al. (1981) showed that the growth rate of timothy increased with increasing latitude. Physiological adaptation to long photoperiods and low temperature, giving a larger leaf area and a prolonged period of vegetative growth due to delayed reproductive development at lower temperatures, are apparently the main factors behind the high spring growth rate in the north (Heide et al. 1985; Hay and Pedersen 1986). Solmaug (1985) also found a larger leaf area index in the North-Norwegian timothy cultivar 'Engmo', as compared with cultivars from the south of Norway.

Breeding for higher yield (i.e. increased harvest index), can be done either by selection and crossing within adapted local populations and cultivars, or by crossing cultivars and ecotypes from other regions with adapted material. Extensive variability trials have shown that sufficient genetic variation exists for herbage yield characteristics within populations from northern areas (SIMONSEN 1985). Results presented in Table 1 clearly show that the yield can be increased also by crossing populations from southern and northern parts of Scandinavia. 
Table 1. Relative dry matter yield and percentage of spring coverage (third year) in Alta $\left(70^{\circ} \mathrm{N}\right)$ of mixed ${ }^{1}$ half-sib families and cultivars of timothy (AASTVEIT unpubl.)

\begin{tabular}{lrc}
\hline Entry & Rel. yield & $\begin{array}{c}\text { \% spring } \\
\text { coverage }\end{array}$ \\
\hline PC progeny: & & \\
$21 / 79$ & $\underline{112}$ & 48 \\
$23 / 79$ & 108 & $\underline{70}$ \\
$10 / 80$ & 102 & 56 \\
$11 / 80$ & 78 & 56 \\
$12 / 80$ & 106 & 69 \\
$18 / 80$ & 100 & 51 \\
$19 / 80$ & 97 & 67 \\
$20 / 80$ & & \\
Cultivar: & 100 & $\underline{56}$ \\
Engmo (northern) & 97 & 28 \\
Grindstad (southern) & & \\
\hline
\end{tabular}

1 Equal weights of seed of each half-sib family within each polycross were mixed.

PC progeny $23 / 79$, which is a mixture of halfsib families from crosses between the northern cultivar 'Engmo' and the southern cultivar 'Grindstad', gave a higher yield and was more persistent than 'Engmo' in Alta $\left(70^{\circ} \mathrm{N}\right)$. Individual families from the polycross gave even higher yields.

The harvest index is also dependent on species. Firstly, the harvest index is certainly lower for species native to northern marginal regions than for introduced species. The reason is larger, rhizomatous root systems. Secondly, stemmy grasses like Phleum and Bromus probably have higher harvest indices than leafy grasses (Poa and Festuca). Both these aspects can be illustrated by a comparison of Poa pratensis as a native, leafy grass, and Phleum pratense as an introduced, stemmy grass species. Poa starts growing extremely early in spring, and can be cut more frequently than Phleum (Schjelderup and Myrr 1980). Early spring growth is extremely important in northern marginal regions. The basis for the earlier spring growth in Poa as compared with Phleum is larger carbohydrate resources, more rapid differentiation and elongation of fertile tillers, and better adaptation to low temperature (ANDERSEN unpubl., ref. by SIMONSEN
1985). Despite the early spring growth, Poa has to be cut twice in order to compete with Phleum in dry matter production (SCHJELDERUP and MyHr 1980). The high yields of dry matter, produced in one cut by timothy, is evidently linked with its generative development (Rognli 1987 a). Timothy has a single spring requirement for flower induction and initiation. Nearly all tillers of sufficient size become generative and elongate during midsummer, greatly enhancing sink capacity as compared with leafy grasses like $\mathrm{Poa}$ and Festuca.

This can also be looked upon as a question of vegetative vigour and/or reproductive success. The theory of fitness states that populations of perennial species exhibit loss of vigour by not being maximally fit in the environments they exploit, but fit for even harsher environments (crucial incidents) (LEvINS 1968). In herbage grasses, vegetative production is not dependent on reproductive success per se, apart from the establishment phase of leys. In the latter case, ecotypes with higher vegetative vigour, from regions with lesser environmental stress than in marginal environments, should be used. This has been utilized to a great extent by provenance transfers in forest tree cultivation, and is also reflected in variety trials in northern areas. Southern grass (herbage) cultivars are in general more productive than northern ones in the first year, and often also in subsequent years if winter stress is not too severe. In my mind, the differences in vegetative vigour between Poa and Phleum at higher latitudes can be interpreted on this basis. The high biomass production of timothy is partly caused by the lack of reproductive adaptation to northern marginal climates (RoGNLI 1987 a). During migration from south to north, natural selection has mainly operated on the vegetative growth cycle, increasing the survival ability through altered assimilate distribution. On the other hand, the price for reproductive success and survival ability in Poa at higher latitudes is loss of vigour. Northern ecotypes are adapted in the sense that they survive the most 
Table 2. Frost and ice encasement tolerance in cultivars and ecotypes of different grass species (GUDLEIFSSON 1986).

\begin{tabular}{|c|c|c|c|c|}
\hline Species & $\begin{array}{l}\text { Cultivar/ } \\
\text { ecotype }\end{array}$ & Country & $\begin{array}{c}\text { Frost- } \\
\text { tolerance } \\
\mathrm{LT}_{50}\end{array}$ & $\begin{array}{c}\text { Ice } \\
\text { tolerance } \\
\mathrm{LI}_{50} \\
\end{array}$ \\
\hline Poa pratensis & $\begin{array}{l}\text { Holt } \\
\text { Fylking } \\
\text { Delta } \\
(04) \\
(06)\end{array}$ & $\begin{array}{l}\text { Norway } \\
\text { Sweden } \\
\text { Canada } \\
\text { Iceland } \\
\text { Iceland }\end{array}$ & $\begin{array}{l}-14.7 \\
-14.0 \\
-13.7 \\
-13.1 \\
-12.3\end{array}$ & $\begin{array}{l}37 \\
24 \\
15 \\
33 \\
29\end{array}$ \\
\hline Festuca pratensis & $\begin{array}{l}\text { Løken } \\
\text { (Pétursey) } \\
\text { Ensign } \\
\text { Salten } \\
\text { Trader }\end{array}$ & $\begin{array}{l}\text { Norway } \\
\text { Iceland } \\
\text { Canada } \\
\text { Norway } \\
\text { Canada }\end{array}$ & $\begin{array}{l}-11.7 \\
-11.6 \\
-10.8 \\
-10.6 \\
-10.0\end{array}$ & $\begin{array}{r}14 \\
9 \\
11 \\
17 \\
16\end{array}$ \\
\hline Phleum pratense & $\begin{array}{l}(0503) \\
\text { Korpa } \\
(0501)\end{array}$ & $\begin{array}{l}\text { Iceland } \\
\text { Iceland } \\
\text { Iceland }\end{array}$ & $\begin{array}{l}-15.7 \\
-13.8 \\
-13.6\end{array}$ & $\begin{array}{l}36 \\
33 \\
44\end{array}$ \\
\hline Deschampsia spp. & $\begin{array}{l}\text { Nordcoast } \\
\text { (Korpa) }\end{array}$ & $\begin{array}{l}\text { USA } \\
\text { Iceland }\end{array}$ & $\begin{array}{l}-10.3 \\
-10.5\end{array}$ & $\begin{array}{l}50 \\
39\end{array}$ \\
\hline Dactylis glomerata & $\begin{array}{l}\text { (Sámsstadir) } \\
\text { Hattfjelldal } \\
\text { Juno } \\
\text { Leikund } \\
\text { Kay }\end{array}$ & $\begin{array}{l}\text { Iceland } \\
\text { Norway } \\
\text { Canada } \\
\text { Norway } \\
\text { Canada }\end{array}$ & $\begin{array}{l}-9.5 \\
-9.3 \\
-8.9 \\
-8.8 \\
-8.5\end{array}$ & $\begin{array}{r}12 \\
8 \\
14 \\
2 \\
10\end{array}$ \\
\hline $\begin{array}{l}\text { Phalaris } \\
\text { arundinacea }\end{array}$ & $\begin{array}{l}\text { Løken } \\
\text { Grove }\end{array}$ & $\begin{array}{l}\text { Norway } \\
\text { Canada }\end{array}$ & $\begin{array}{r}-6.7 \\
-4.7\end{array}$ & $\begin{array}{l}26 \\
26\end{array}$ \\
\hline
\end{tabular}

severe winters. They are not necessarily well adapted for herbage production.

\section{Resistance to adverse environmental conditions}

The most important factor in northern marginal regions is winterhardiness, a complex characteristic which mainly includes resistance to frost and ice/water cover, and resistance to parasitic low-temperature fungi. LARSEN (1986) pointed out also that desiccation during winter probably causes more damage to grasslands than has been recognized. Our understanding of the complex genetic and physiological mechanisms, especially the hardening process in relation to climate, is still incomplete, and makes breeding for winterhardiness very difficult. Table 2 presents results from a frost tolerance and ice encasement test of different varieties of seven species (GUDLEIFSON 1986). Phleum pratense and Poa pratensis are the most frost tolerant, Festuca praten- sis and Deschampsia spp. are less so, and Dactylis glomerata and Phalaris arundinacea are most susceptible to frost injury. Both $P$. pratense, $P$. pratensis, Deschampsia spp. and $P$. arundinacea are generally tolerant against ice encasement, while $F$. pratensis and $D$. glomerata are sensitive to this kind of stress. Red clover is very sensitive to ice encasement and water logging, and survives best in continental regions with stable snow cover. The latitudinal cline in winterhardiness, increasing with latitude, is well documented, and largely governed by differences in seasonal growth rhythm. As regards cultivar differences, the degree of tolerance towards a certain winter stress factor is largely dependent on the type of winter climate to which they have been adapted. In general, cultivars from regions with continental winter climate are frost resistant, and have good resistance against lowtemperature fungi, while cultivars from maritime regions are less frost resistant, but tolerate ice encasement following freeze-thaw os- 
cillations. Klebesadel and Helm (1986) found that, although northern timothy cultivars were very winter-hardy in Alaska, native species with rhizomatous root systems were better adapted to very instable, maritime winter climates. This adaptation is certainly a result of better regrowth ability.

Genetic variation for winter survival seems to be low within adapted plant material (SCHJelderup 1982). This is not unexpected in view of the strong natural selection they have undergone. Preliminary results from the NoRDGRAs work indicate that differences in winterhardiness are more dependent on local differences in climate than genetic differences between cultivars (ANON. 1986). Breeding for winterhardiness will be very important in cases where non-adapted material is introduced.

A major restriction on northern expansion of perennial ryegrass (Lolium perenne) is the susceptibility to low-temperature fungi (JönsSON and NILSSON 1986). Ryegrass is apparently not adapted to live under long-lasting snow cover, and a strategy for adaptation of ryegrass to short-term leys in northern regions should be developed. JönSSON and NILSSON (1986) improved the resistance to Fusarium nivale by phenotypic selection in diploid ryegrass, while the response was rather uncertain in tetraploids. Table 3 presents some results taken from the official Norwegian herbage variety trials (five locations in SouthNorway, second harvest year). Among the ryegrass material there is a strong positive correlation between the relative amount of dry matter produced in the first cut and winter survival $(r=0.83)$. A further shift in the seasonal distribution may be necessary in order to increase northern adaptation of perennial ryegrass. Ryegrass seems to have a remarkable ability to recover in spring after injury by low-temperature fungi.

\section{Nutritive value and persistence}

Forage grasses are the dominating part of the roughage in northern marginal regions, and high nutritive value is therefore particu- larly important (SIMONSEN 1985). The nutritive value or quality is influenced by many factors. These include species and species composition, climate, timing and frequency of cutting, fertilization and conservation. Timothy is regarded as the most palatable and nutritive grass species in these regions.

A major problem is to obtain both high productivity, high quality and persistency at the same time. Persistency is partly dependent on the species, but also largely influenced by the management system. SCHJELDERUP (1983 b) found that timothy and meadow fescue were much more sensitive to the effects of soil compaction by heavy machinery than Kentucky bluegrass. If the intention is to produce a long-lasting meadow, then indigenous rhizomatous species like Poa and Phalaris should be used. Then one probably has to accept lower biomass production per year, and certainly lower quality. In shortterm leys, i.e. 3-4-year crop rotation, introduced species like Phleum, F. pratensis and D. glomerata will be the most valuable. Experiences of different cutting systems have shown that timothy can be cut only once in marginal regions in order to persist. High dry matter production may then be obtained by cutting fairly late. A breeding strategy for a "one-cut» cultivar could therefore be to maximize dry matter production by selecting for a high fertile tiller number, which increases sink capacity, and to secure good quality by selecting genotypes with a slow decline in digestibility after heading (RogNLI 1987 a). McElroy and Christie (1986) estimated an increase of $2-3$ percentage points in in vitro digestibility (IVD) at anthesis following this strategy.

Clover is very little used in the northern regions, but will certainly be more important in the near future because herbage quality is given high priority. HAGSAND and LANDSTRÖM (1984) found that even if the content of red clover in meadows in northern Sweden was low after 5-6 years, it still contributed a lot and gave higher yields of better quality than pure timothy meadows. The present northern 
Table 3. Seasonal distribution of dry matter yield and winter survival in varieties and Norwegian breeding populations of Lolium perenne.

\begin{tabular}{|c|c|c|c|c|c|c|}
\hline \multirow{2}{*}{\multicolumn{2}{|c|}{ Entry }} & \multicolumn{3}{|c|}{ Relative amount of DM } & \multirow{2}{*}{$\begin{array}{l}\text { Relative } \\
\text { DM yield }\end{array}$} & \multirow{2}{*}{$\begin{array}{c}\text { winter } \\
\text { survival } \%\end{array}$} \\
\hline & & cut 1 & cut 2 & cut 3 & & \\
\hline Taptoe N & NL & 50 & 37 & 13 & $\underline{100}$ & $\underline{53}$ \\
\hline Bonita (4n) N & NL & 51 & 37 & 12 & 97 & 52 \\
\hline Tove (4n) I & DK & 50 & 37 & 13 & 99 & 49 \\
\hline Svea (2n) S & $\mathrm{S}$ & 55 & 34 & 11 & 91 & 89 \\
\hline Raigt 1 (4n) $N$ & $\mathrm{~N}$ & 55 & 34 & 10 & 90 & 61 \\
\hline Raigd2(2n) & $\mathrm{N}$ & 49 & 39 & 12 & 87 & 58 \\
\hline Raigd3(2n) $N$ & $\mathrm{~N}$ & 56 & 34 & 10 & 95 & 81 \\
\hline Raigt4 (4n) $N$ & $\mathrm{~N}$ & 57 & 33 & 10 & $\underline{100}$ & $\underline{80}$ \\
\hline Fure $(4 n) N$ & $\mathrm{~N}$ & 54 & 36 & 10 & 95 & 74 \\
\hline Forus timoth & hy & 62 & 30 & 8 & 97 & 94 \\
\hline
\end{tabular}

cultivars of red clover are not winter-hardy enough for use in the most marginal regions. White clover is native, and could replace red clover in these areas. Breeding work has been undertaken in northern Norway to develop cultivars both for grazing and conservation.

\section{Seed production}

Two aspects of seed production are particularly important in relation to breeding at higher latitudes. The first is the seed yield level of the cultivars. Results from seed production studies have shown that existing ecotypes and cultivars in general are very good seed producers. They often produce more seed than cultivars from southern Scandinavia, as shown for timothy by SKAARE and Hillestad (1974). This indicates a higher reproductive potential in the northern timothy cultivars than in the southern ones, which may be a result of past adaptation to hay production (RoGNLI 1987 a). In highly rhizomatous species like Poa and Phalaris, the seed yields decrease very rapidly with increasing tiller density.

The second aspect is concerned with the localization of seed production. The climatic conditions at higher latitudes are unfavourable for commercial seed production. The main problem is low seed quality, and large year to year variations in yield. However, the potential seed yield is often as high in the north as in the south (HẢBJøRg 1979 b; RognLI 1987 a). HÁвJørg (1979 b) found that the Norwegian Poa pratensis ecotypes produced the highest yields of seed at continental, highlatitude locations. Finding locations in the north, where elite seed production of northern cultivars could be located, has been a major objective for the NORDGRAS project (ANON. 1986). Elite seed production of cultivars which are populations (seed elite), must be kept in the region of origin in order to avoid genetic shifts. The multiplication scheme that has been chosen for the NorthNorwegian timothy cultivars, with elite seed produced in the north, basic seed in the middle, and certified seed in the south of Norway, has been successful. Elite seed of synthetic cultivars (based on clones), may in principle be produced anywhere. However, great genotype $\mathrm{x}$ environment-interactions in seed production may affect the genetic stability when seed is produced in different environments (RogNLi 1987 b). Selection of clones with high phenotypic stability of seed production when breeding synthetic varieties, could be a means of reducing the risk of genetic shifts. GxE interactions, caused by specific adaptation to high-latitude daylengths and temperatures, have resulted in low and unpredictable seed yields of the northern cultivars of Poa pratensis and Phalaris arundinacea. SIMONSEN (1985) advocated to eliminate the most extreme long-day geno- 
types from the breeding material in order to reduce the latitudinal effects on seed production. This procedure may be seen as a kind of phenotypic stabilizing selection.

As thoroughly discussed by RogNLI (1987 a), the management of elite seed production of northern cultivars may be of vital importance for the vegetative productivity of the cultivars.

\section{Concluding remarks}

High-input agriculture requires much energy and causes environmental problems. Therefore, there is an increasing interest in lowinput agriculture in the developed world to- day. Plant production will in the future probably be undertaken under more natural conditions. Breeding for the margin, or environmental stress, will be increasingly important. High yield levels in northern marginal regions are probably more dependent on fertilizers than in more optimal environments. A discussion of the impact of low-input agriculture on the structure of northern herbage production should be started among the breeders. Do we have to rely on indigenous species like Agrostis tenuis, Festuca rubra, Deschampsia caespitosa, which are adapted to acid and infertile soils, and Poa pratensis on more productive land, or can we still utilize productive, high-input species in the future?

\section{References}

ANON. 1986. Forædling av græsmarksplanter til nordens nordligste områder. - Report given from NORDGRAS-project, SNP, 33 pp.

BıLıIngs, W.D. 1974. Plant adaptations to cold summer climates. In: "Arctic and Alpine Environments", (Eds. J.D. Ives, J. Berry), London, Methuen, 403-443.

Bradshaw, A.D. 1971. Plant evolution in extreme environments. - In: "Ecological Genetics and Evolution", (Ed. Creed), Blackwell Sci. Publ., Oxford, $20-50$.

Deinum, B., de Beyer, J., Nordfeldt, P.H., Kornher, A., Østgárd, O. \& van Bogaert, G. 1981. Quality of herbage at different latitudes. - Neth. J. Agric. Sci. 29: $141-150$.

Eagles, C.F. \& Østgárd, O. 1971. Variation in growth and development in natural populations of Dactylis glomerata from Norway and Portugal. I. Growth analysis. - J. Appl. Ecol. 8: 367-381.

FLoviK, K. 1938. Cytological studies of arctic grasses. Hereditas 24: 265-376.

Foss, S. 1968. Vekstrytme hos timoteisorter. - Forsk. Fors. Landbr. 19: 487-518.

GudLeıfson, B.E. 1986. Måling av isdekketoleranse hos gras i laboratoriet. - NJF-seminary report 84 , MTTK, Jokioinen, 171-179.

Hagsand, E. 1985. Växtodlingen i norra Finland, Norge och Sverige. - Sveriges Utsådesförenings tidsskrift, 95: 173-191.

- \& LANDSTROM, S. 1984. Ensidig grovfoderodling i Norra Sverige. - Röbäcksdalen Meddelar, 1984 (4), $74 \mathrm{pp}$.

HAY, R.K.M. \& Pedersen, K. 1986. Influence of long photoperiods on the growth of timothy (Phleum

pratense $\mathrm{L}$.) varieties from different latitudes in northern Europe. - Grass and Forage Science, 41: 311-317.

Heide, O.M. 1980. Studies on flowering in Poa pratensis L. ecotypes and cultivars. - Meld. Norg. Landbr. Høgsk. 59 (14): 1-27.

- 1982. Effects of photoperiod and temperature on growth and flowering in Norwegian and British timothy cultivars (Phleum pratense L.). - Acta Agric. Scan. 32: $241-252$.

- 1985. Physiological aspects of climatic adaptation in plants with special reference to high-latitude environments. - In: "Plant Production in the North" (Eds. A. Kaurin, O. Junttila, J. Nilsen), Norwegian University Press, 1-22.

-, HaY, R.K.M. \& Baugerød, H. 1985 a. Specific daylength effects on leaf growth and dry matter production in high-latitude grasses. - Ann. Bot. 55: 579-586.

HÄвJørG, A. 1979 a. Floral differentiation and development of selected ecotypes of Poa pratensis L. cultivated at six localities in Norway. - Meld. Norg. Landbr. Høgsk. 58 (4), 19 pp.

- 1979 b. Seed production studies in latitudinal and altitudinal distant types of Poa pratensis L. cultivated at nine localities in Norway. - Meld. Norg. Landbr. Høgsk. 58 (28), 18 pp.

Jonsson, H.A. \& Nilsson, C. 1986. Plant breeding for resistance to snow moulds in grasses. - NJF-seminary report 84, MTTK, Jokioinen, 145-148.

KLEBeSADEL, L.J. 1985. Adaptational changes induced in temperate-adapted forage legumes by natural selection pressures in subarctic Alaska. - In: "Plant Production in the North" (Eds. A. Kaurin, O. Junttila, J. Nilsen), Norwegian University Press, 304-315. 
- \& Helm, D. 1986. Food reserve storage, lowtemperature injury, winter survival, and forage yields of timothy in subarctic Alaska as related to latitudeof-origin. - Corp. Sci. 26: 325-334.

LARSEN, A. 1986. Test methods for wintering characters. - NJF-seminary report 84 , MTTK, Jokioinen, 149166.

LEvins, R. 1968. Evolution in changing environments: some theoretical explorations - Population Biol. Monogr. 2, Princeton Univ. Press, $120 \mathrm{pp}$.

LOMAKKA, L. 1958. Naturgeografiska förhållanden i norra Fennoscandia. - Nordisk Jordbruksforskning, 40: 144-351,

McElroy, A.R. \& Christie, B.R. 1986. Variation in digestibility decline with advance in maturity among timothy (Phleum pratense L.) genotypes. - Can. J. Plant. Sci. 66: 323-328.

Nesheim, L. 1986. A grassland survey in Nordland, North Norway II. Botanical composition and influencing factors. - Meld. Norg. Landbr. Høgsk. 65 (19), $60 \mathrm{pp}$.

Ravantti, S. \& Kajaste, S. 1986. Vallväxternas vinterhärdighetsförädling i Finland. - NJF-seminary report 84, MTTK, Jokioinen, 195-203.

RognLı, O.A. 1987 a. Genetic variation in arctic populations of timothy (Phleum pratense L.). I. Seed production characters. Hereditas 107: 27-54.

$-1987 \mathrm{~b}$. Genetic variation in arctic populations of timothy (Phleum pratense L.). II. Phenotypic stability of seed production. - Hereditas 107: 75-94.

\section{SELOSTUS}

\section{Nurmiheinien lajikohtaisia jalostustavoitteita viljelyn pohjoisia raja-alueita varten}

\section{Odd Arne Rognli}

\author{
Department of Genetics and Plant Breeding, \\ Agricultural University of Norway, \\ N-1432 As-NLH, Norway
}

Pohjoiset raja-alueet muodostavat hyvin epäyhtenäisen viljely-ympäristön. Alhainen lämpötila on kuitenkin hallitseva ympäristótekijä. Luonnonvalinnan vaikutus ja pohjoisten nurmikasvipopulaatioiden sopeutuminen ilmastoon muodostavat eri lajien jalostustavoitteiden tarkastelun perustan. Erot alueen alkuperäisten lajien, kuten nurmikka (Poa pratensis), punanata (Festuca rubra) ja lauha (Deschampsia spp.) sekä toisaalta tänne tuotu-
SChjelderup, I. 1982. Test of local grass populations in North Norway. - In: „Utilization of Genetic Resources in Fodder Crop Breeding", Report from a meeting in EUCARPIA Fodder Crops Section, Aberystwyth, Wales, 1982, 168-171.

- 1983 a. Plantemateriale sett i relasjon til brukspress. - In: "Engvekstforedling III, 1983", NLVF/SFL, $167-174$.

-1983 b. Tilvekst og avkastning hos aktuelle grasarter. - Report no. 416, NLVF, Oslo, 13 pp.

— \& MrнR, K. 1980. Arts- og sortsforsøk med rapp. Forsk. Fors. Landbr. 31: 131-143.

SIMONSEN, Ø. 1985. Herbage breeding in northern areas. - In: "Plant Production in the North» (Eds. À. Kaurin, O. Junttila, J. Nilsen), Norwegian University Press, 277-295.

SkaAre, S. \& Hillestad, R. 1973. Fröavkastning av timoteisorter. - Forsk. Fors. Landbr. 24: 439-449.

Solmaug, K.A. 1985. Photosynthesis and respiration in three timothy (Phleum pratense L.) cultivars with different growth rhythms. - In: "Plant Production in the North" (Eds. A.. Kaurin, O. Junttila, J. Nilsen), Norwegian University press, 254-259.

Thomasson, T. 1984. A grass from Alaska gives promising results in Icelandic trials. - Agroborealis 16: 33-36.

Tigerstedt, P.M.A. 1985. Genetic mechanisms for adaptation. - In: "Plant Production in the North" (Eds. A.. Kaurin, O. Junttila, J. Nilsen), Norwegian University Press, 205-218.

jen lajien, timotei (Phleum pratense) ja nurminata (Festuca prantensis), ovat merkittăviă. Erot kohdistuvat joukkoon tärkeită ominaisuuksia, kuten sadontuottokykyyn, kasvurytmiin, laatuun ja talvenkestävyyteen. Viimeksi mainittu on pohjoisiin oloihin sopeutumisen tärkein ominaisuus. Erityisesti timoteita kohteena käyttäen tarkastellaan tuottavuuden eri osatekijäin keskinäisiä suhteita. 